\title{
KAJIAN AKSES MASYARAKAT DALAM PENGELOLAAN GALIAN PASIR DI SUB DAERAH ALIRAN SUNGAI CIATEN, CISADANE HULU
}

\author{
Study of Community Access in Management of Sand In the Ciaten River Basin, \\ Upstream Cisadane
}

\author{
Messalina L Salampessy ${ }^{\star 1},{ }^{2}$ Indra G Febryano, ${ }^{3}$ Andi Chairil Ichsan, ${ }^{4}$ Ina Lidiawati \\ ${ }^{1,4}$ Fakultas kehutanan, Universitas Nusa Bangsa. Bogor, Jawa Barat, Indonesia. \\ 2. Jurusan Kehutanan, Fakultas Pertanian Universitas Lampung, Indonesia \\ 3.Program studi Kehutanan, Fakultas Pertanian Universitas Mataram Lombok, Indonesia
}

*Email: meisforester76@gmail.com

Direvisi: 11/05/2020, Diterbitkan: 01/08/2020

\begin{abstract}
Community access to obtain, control and regulate the use of natural resources around watersheds (DAS) will have an influence on the sustainability of the functions and roles of the watershed. This study aims to describe and explain the access of the community in the utilization of excavated $\mathrm{C}$ resources around the watershed. This research was conducted in May-October 2017 in the village of Cemplang, Cibungbulang, Bogor, especially in the Ciaten Cisadane Hulu sub-watershed. Data obtained through in-depth interviews and focus group discussions (FGD) were then analyzed qualitatively using the theory of access from Ribot and Peluso. The results show that various stakeholders / actors were directly involved in natural resource utilization activities in excavation $\mathrm{C}$, especially in sand mining activities in Cemplang village, among others: Village government, mining landowners / entrepreneurs and communities around the sand mining land. Each actor has different interests in the existence of a watershed both socially, economically and ecologically; as well as the power they have. Therefore, the management of the natural resources of the watershed must be carried out in a participatory and adaptive manner so that the sustainability of the watershed functions remains sustainable.
\end{abstract}

Keywords: Access, actors, upstream Cisadane watershed, excavation C.

\begin{abstract}
ABSTRAK
Akses masyarakat untuk memperoleh, mengontrol dan mengatur pemanfaatan sumberdaya alam di sekitar Daerah aliran sungai (DAS) akan memberi pengaruh bagi kelestarian fungsi dan peranan DAS tersebut. Penelitian ini bertujuan untuk menguraikan dan menjelaskan akses masyarakat dalam pemanfaatan sumberdaya galian $\mathrm{C}$ di sekitar DAS. Penelitian ini telah lakukan pada bulan Mei-Oktober 2017 di desa Cemplang Kecamatan Cibungbulang Bogor khususnya di sub DAS Ciaten Cisadane Hulu. Data diperoleh melalui wawancara mendalam dan Diskusi Kelompok terarah (FGD) kemudian dianalisis secara kualitatif mengunakan teori akses dari Ribot dan Peluso. Hasil menunjukkan bahwa teridentifikasi berbagai pemangku kepentingan/aktor yang terlibat langsung dalam aktifitas pemanfaatan sumberdaya alam di galian C khususnya pada aktifitas penambangan pasir di desa Cemplang antaralain : Pemerintah desa, pemilik/pengusaha lahan penambangan dan masyarakat sekitar lahan penambang pasir. Setiap aktor memiliki kepentingan yang berbeda terhadap keberadaan DAS baik secara sosial, ekonomi maupun ekologi; begitu pula dengan kekuasaan yang di miliki. Oleh karena itu pengelolaan Sumberdaya alam DAS harus dilakukan secara partisipatif dan adaptif agar kelestarian fungsi DAS tetap lestari.
\end{abstract}


Kata kunci: Akses, aktor, DAS Cisadane hulu, galian C.

\section{PENDAHULUAN}

Pengelolaan Daerah aliran sungai (DAS) menjadi aspek penting dalam menunjang pelestarian kawasan sekitarnya. Fungsi daerah hulu sebagai daerah tangkapan air harus dijaga dengan menjaga agar pemanfaatan kawasan agar terhindar dari daya dukung yang melebihi lingkungan. Peran masyarakat di daerah sekitarnya menjadi upaya penting untuk menjaga kelangsungan fungsi DAS (Salampessy.M.et al, 2017)

Sebagian besar wilayah Kabupaten Bogor berfungsi sebagai kawasan penyangga, dikarenakan secara geografis letaknya di bagian hulu. Namun demikian, aksesibilitas yang tinggi menjadikan Kabupaten Bogor sebagai salah satu pusat pengembangan permukiman perkotaan dan pusat kegiatan perekonomian, seperti: penghasil produk pertanian, perdagangan dan jasa (wisata alam dan wisata kuliner), kawasan industri (industri kecil maupun industri menengah) dan lain sebagainya. Menurut (Alberto et. al. 2010., 2110), DAS Cisadane merupakan salah satu DAS yang penting di provinsi Jawa Barat, kaya sumber daya alam digunakan untuk kebutuhan sehari-hari, dan juga DAS yang rentan terhadap perubahan penggunaan lahan, terutama di daerah Bogor dan Tangerang dengan kepadatan penduduknya relatif tinggi.

DAS merupakan suatu ekosistem yang terdiri dari unsur biotik dan abiotik yang terletak di bentangan alam dan bukan merupakan suatu wilayah administrasi tetapi mempunyai nilai ekologis penting karena fungsinya sebagai kawasan resapan air, kawasan perlindungan setempat, kawasan konservasi tanah dan air, dan fungsi hidrologisnya(Trimarmanti.T.K.E, 2014). Perkembangan masyarakat di wilayah DAS dapat mempercepat perubahan pola pemanfaatan Sumberdaya Alam (SDA) yang ada. Pemanfaatan yang kurang memperhatikan kaidah konservasi lahan mengakibatkan degradasi kondisi DAS di daerah Hulu. Saat ini masyarakat di sekitar Hulu timur DAS Cisadane memiliki akses dan ketergantungan yang tinggi dalam memanfaatkan sumberdaya alam disekitar DAS. Akses masyarakat untuk memperoleh, mengontrol dan mengatur pemanfaatan SDA di sekitar DAS memegang peranan penting bagi kelestarian fungsi dan peranan DAS.

Kelimpahan dan kekurangan sumber daya alam akan memberikan implikasi meningkatkan konflik sosial (Wegenast.T.and Schneider. G, 2017). (Buckles, 1999) menjelaskan bahwa ada 4 (empat) penyebab timbulnya konflik dalam pengelolaan sumber daya alam yaitu: Pertama, adanya perbedaan akses antar aktor sosial dan/atau institusi terhadap pusat kekuasaan. Kedua, aktivitas manusia yang cenderung mengubah keseimbangan ekosistem di suatu wilayah sehingga menimbulkan masalah lingkungan di wilayah lainnya. Ketiga, adanya peningkatan kalangkaan sumber daya alam (natural resources scarcity) yang disebabkan oleh terjadinya perubahan lingkungan, pertumbuhan penduduk dan peningkatan permintaan, serta pola pendistribusian yang tidak merata. Keempat, sumber daya alam dipergunakan oleh manusia bukanlah semata mata sebagai material yang perebutkan, namun juga untuk mendefinisikan hidupnya secara simbolis.

Relasi kekuasaan di antara para aktor yang tidak setara merupakan dampak dari politisasi lingkungan (politicized environment) (Bryant R.L and \& Bailey, 1997). Politisasi lingkungan adalah adanya pusat kekuasaan atau dominasi aktor negara dan swasta terhadap sumber daya alam. Akibat dari dominasi tersebut, membatasi akses bagi sebagain aktor lainnya, terutama aktor akar rumput yaitu aktor lokal (Bryant R.L and \& Bailey, 1997) Akhirnya, muncul asumsi baru yang diungkapkan (Bryant R.L., 1998) : Pertama, biaya dan manfaat yang berhubungan dengan perubahan lingkungan didistribusikan di antara berbagai aktor secara tidak merata. Kedua, distribusi biaya dan manfaat yang tidak merata dapat menyebabkan terjadinya berbagai ketimpangan sosial ekonomi. Ketiga, akibat adanya berbagai ketimpangan sosial ekonomi, akhirnya merubah berbagai relasi kuasa di antara aktor-aktor. Relasi kuasa diantara aktor berkaitan dengan kekuasaan aktor untuk 
mengontrol, memperoleh, dan mempertahankann aksesnya terhadap sumber daya (Ribot. J.C and Peluso.N.L, 2003) Relasi kuasa yang terjadi dalam pengelolaan sumber pasir dan batu yaitu relasi kuasa antar kelompok masyarakat dalam memperoleh sumber daya tersebut yang memiliki nilai sosial, ekonomis, budaya dan politik. Selain itu, relasi kuasa terjadi antara kelompok pemilik lahan karena adanya wilayah penambangan yang sama dan adanya pembatasan akses oleh pihak desa turut berpengaruh.

Oleh karena itu, penelitian yang dilakukan ini memberi perhatian pada mekanisme akses masyarakat dalam pemanfaatan sumberdaya alam di pesisir Hulu timur Das Cisadane Bogor terutama dalam aktivitas galian $\mathrm{C}$ (pasir dan batu). Pengetahuan dan pemahaman tersebut akan bermanfaat bagi berbagai pihak yang terkait dalam membuat rekomendasi pengelolan DAS yang adil, sejahtera dan berkelanjutan.

\section{METODE}

Penelitian ini dilakukan dari bulan Mei hingga Oktober 2017 di hulu sungai Cianten, terutama di Desa Cemplang, Kabupaten Bogor. Objek penelitian ini adalah aktifitas penambangan galian $\mathrm{C}$ yang dilakukan masyarakat setempat. Desa Cemplang dipilih karena merupakan daerah di daerah hulu DAS Cisadane yang memiliki aktifitas penambangan pasir yang cukup tinggi. Lokasi penelitian dapat dilihat pada gambar 1.

Metode pengambilan sampel adalah pengambilan sampel secara purposive dengan kriteria merupakan penambang pasir dengan usia antara 18-60 tahun dan telah beraktivitas dilokasi tersebut minimal 5 tahun. Hingga diperoleh keseluruhan jumlah responden adalah 25 orang yang mewakili 10 orang penambang pasir, 10 orang masyarakat setempat dan 5 orang pemilik lahan dan aparatur desa. Metode pengumpulan data yang digunakan adalah wawancara, observasi dan studi literatur. Penelitian ini mengunakan metode studi kasus dimana peneliti mengambarkan dan menemukan fenomena yang kunci yang nampak dari aspek aktifitas masyarakat dalam pemanfaatan SDA khusus galian C. (Yin.K.R, 1997). Pendekatan analisisnya bersifat deskriptif untuk mengumpulkan informasi tentang status gejala yang dilakukan, tidak dimaksudkan untuk mengukur hipotesis tertentu, tetapi hanya menggambarkan apa itu tentang variabel, gejala, dan keadaan.

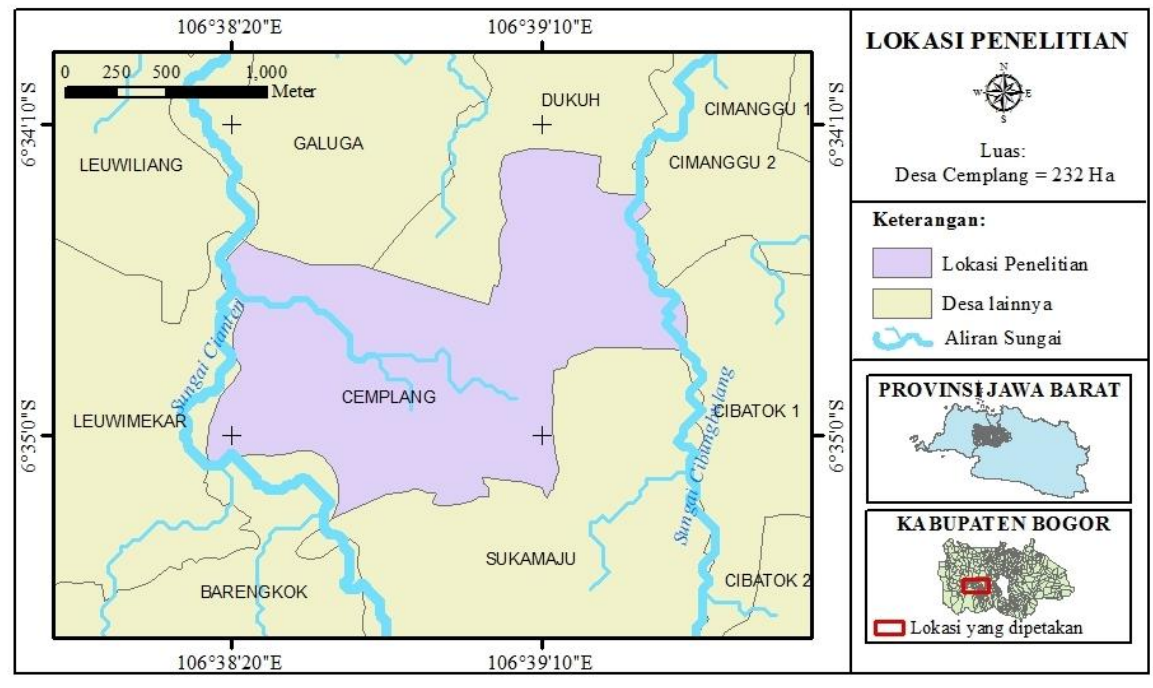

Gambar 1. Peta lokasi Penelitian

Figure 1. Map of Location research

Penelitian ini menggunakan pendekatan aktor (Bryant R.L and \& Bailey, 1997) yang memberikan penjelasan peran dan kepentingan aktor terhadap sumber daya DAS khususnya galian pasir. Pendekatan aktor dikombinasikan dengan teori akses (Ribot. J.C 
and Peluso.N.L, 2003) Ada dua mekanisme terbentuknya akses menurut (Ribot. J.C and Peluso.N.L, 2003) yaitu, Pertama, mekanisme right-based access (akses berbasis hak), seperti adanya ketetapan hukum melalui Undang-undang, hukum adat istiadat, dan konvensi atau kesepakatan yang terbentuk dari keputusan diantara aktor. Akses legal, ditentukan berdasarkan hukum, adat, dan konvensi. Sedangkan akses ilegal beroperasi melalui paksaan (melalui kekerasan atau ancaman) dan diam-diam membentuk hubungan diantara aktor yang mencoba untuk mendapatkan, mengendalikan, atau mempertahankan akses. Kedua, mekanisme structural and relational access (akses relasional dan struktural) yaitu, kemampun untuk mendapatkan keuntungan dari sumber daya yang dibingkai politikekonomi dan budaya. Mekanisme struktural dan relasi sosial melalui basis kekuasaan yang terdiri dari teknologi, pengetahuan, modal, otoritas, identitas sosial dan relasi sosial dalam bentuk rasa saling percaya, persahabatan dan rasa tanggungjawab.

\section{HASIL DAN PEMBAHASAN}

\section{Gambaran Umum Wilayah DAS.}

DAS Cisadane terletak pada $6^{\circ} 72^{\prime}$ sampai $6^{\circ} 76^{\prime}$ LS dan $106^{\circ} 58^{\prime}$ sampai $106^{\circ} 51^{\prime}$ BT, terbagi menjadi 4 sub DAS, yaitu 2 di bagian hulu (Cianten dan Cisadane Hulu), 1 sub DAS di bagian tengah dan 1 sub DAS di bagian hilir. Berdasarkan batas administrasi, DAS Cisadane mencakup 518 desa yang tersebar di 44 kecamatan di 5 kabupaten/kota yaitu Kabupaten Bogor, Kota Bogor Kabupaten Tangerang, Kota Tangerang, dan Kota Tangerang Selatan (BPDAS Citarum-Ciliwung, 2010)

DAS Cisadane mempunyai ketinggian yang sangat beragam dengan dominasi daerah yang berbukit dan bergelombang. Pada sub DAS Cisadane Hulu 45,6\% wilayahnya berada pada ketinggian 200-500 m, sedangkan sub DAS Cianten 40,5\% wilayahnya berada pada ketinggian 500-1000 m. Wilayah tengah dan hilir DAS Cisadane didominasi oleh daerah yang relatif landai dengan ketinggian 0-200 m. Kawasan hijau tersebar lebih banyak di bagian hulu yaitu $\pm 33 \%$. Penutupan lahan di bagian hulu di dominasi oleh lahan pertanian semusim, ladang, sawah dan tegalan (BPDAS Citarum-Ciliwung, 2010).

Jumlah penduduk di DAS Cisadane berdasarkan sensus penduduk tahun 2010 yaitu 3,49 juta jiwa dengan tingkat kepadatan penduduk 23 juta jiwa/Ha, dengan sebaran penduduk paling banyak di sub DAS Cisadane Tengah $39,8 \%$ dan sub DAS Cisadane Hulu $30 \%$. Beberapa kecamatan mengalami $>30 \%$ kenaikan jumlah penduduk tahun 2005 hingga 2010 yaitu Ciomas, Dramaga, Caringin, Parung, dan Rumpin.

Desa Cemplang adalah salah satu desa yang berada tepat di sekitar hulu timur DAS Cisadane khususnya pada sungai ciaten. Secara ekologis keberadaan Sub Das hulu Cisadane mendukung keseimbangan ekosistem sehingga diwilayah ini banyak dijumpai sumberdaya alam yang cukup melimpah, mencakup sumber daya hutan dan satwa liar, dll. Sumberdaya lahan dan sumber daya air yang semuanya itu memberikan manfaat ekonomi bagi penduduk yang mendiami wilayah DAS tersebut. Penduduk Desa Cemplang merupakan warga penduduk asli. Aktifitas yang paling banyak dijumpai diwilayah Sub DAS adalah penambangan pasir tradisional. Aktifitas penambangan pasir ini telah di geluti masyarakat \pm 40 tahun dan diprakrasai oleh 3 tokoh pemilik lahan. Pendapatan masyarakat yang rendah dan tingkat pendidikan formal masyarakat yang juga rendah, serta kurangnya edukasi kepada masyarakat untuk menjaga dan melestarikan fungsi lingkungan turut mempengaruhi perilaku masyarakat dalam pemanfaatan sumberdaya alam di wilayah ini. Status sosial dari pemilik lahan atau tuan tanah yang memiliki wewenang dan kuasa penuh terhadap hak ulayatnya sangat berpengaruh terhadap perilaku masyarakat dalam pemanfaatan sumberdaya alam. Aktivitas pemanfaatan sumberdaya alam tersebut dilakukan untuk pemenuhan kebutuhan pokok dan juga kebutuhan ekonomi masyarakat. 


\section{Kekuasaan Aktor Untuk Mengakses Sumberdaya Pasir Di DAS}

Penambangan skala kecil bentuk perizinan yang diperlukan adalah berupa Izin Pertambangan Rakyat (IPR) dan bisa dimiliki perorangan atau kelompok atau berupa koperasi atau badan usaha yang dikeluarkan oleh instansi yang berwenang untuk mengurus soal pertambangan ini melalui Dinas Pertambangan dan Energi di Kabupaten Bogor.( UU No. 4 tahun 2009 ).

Adapun implementasi pengaturan izin usaha galian golongan $\mathrm{C}$ ditinjau dari perspektif hukum administrasi negara yaitu UU No. 4 tahun 2009 tentang Pertambangan UU No. 4 tahun 2009 tentang Pertambangan Mineral dan Batubara, UU No. 32 tahun 2009 tentang Perlindungan dan Pengelolaan Lingkungan Hidup, Peraturan Pemerintah No. 55 tahun 2010 tentang Pembinaan dan Pengawasan Penyelenggaraan Pengelolaan Usaha Pertambangan Mineral dan Batubara, Peraturan Pemerintah No. 24 tahun 2012 tentang Perubahan atas Peraturan Pemerintah No. 23 tahun 2010 tentang Pelaksanaan Kegiatan Pertambangan Mineral dan Batubara, Inpres No. 1 tahun 2012 tentang Pelaksanaan dan Pengawasan terkait Kegiatan Usaha Batubara.

Aktifitas penambangan pasir di desa Cemplang berlangsung pada 2 kampung yaitu kampung Babakan Rendah dan kampung pasir angin. Kegiatan Penambangan galian C khususnya batu dan pasir dari sungai Cianten dilakukan oleh masyarakat setempat dan digeluti oleh 10 orang penambang yang merupakan warga asli setempat.

Relasi kekuasaan dapat terjadi dalam bentuk konflik atau kompetisi, kerjasama (negosiasi) dan perlawanan dalam memperoleh manfaat dari sumber daya (Ribot. J.C and Peluso.N.L, 2003), (Bryant R.L and \& Bailey, 1997) dan Scott 1990). Konflik atau kompetisi tentunya akan dimenangkan oleh aktor yang memiliki bundle of power yang lebih besar dibandingkan aktor lainnya. Aktor yang memiliki kekuasaan lebih banyak dapat mempengaruhi aktor lain dalam mengontrol, mempertahankan (memanfaatkan), dan memelihara sumber daya yang tersedia (Febryano, I.G., D. Suharjito, 2015) ; Priyatna et al., 2013). Relasi kekuasaan dalam pengelolaan sumber daya pasir dan batu di sungai ciaten ini setidaknya terdapat beberapa aktor yang saling berinteraksi, yaitu Pemerintah desa, pemilik/pengusaha penambangan, penambang pasir dan masyarakat sekitar lahan penambang pasir. Terlihat pada tabel 2 sebagai berikut :

Tabel 2. Kekuasaan aktor dalam mengakses sumberdaya Galian $\mathrm{C}$ Table 2. The power of actors in accessing resources Excavition $C$

\begin{tabular}{|c|c|c|c|}
\hline Aktor & Kepentingan & Mekanisme Akses & Kekuasaan Aktor \\
\hline Pemerintah Desa & $\begin{array}{l}\text { Kewenangan terhadap } \\
\text { wilayah penambangan }\end{array}$ & $\begin{array}{l}\text { Berbasis Hak, } \\
\text { Struktural Dan } \\
\text { Relasional }\end{array}$ & $\begin{array}{l}\text { Kekuasaan } \\
\text { Identitas dan relasi } \\
\text { sosial }\end{array}$ \\
\hline $\begin{array}{l}\text { Pemilik/Pengusaha } \\
\text { Galian }\end{array}$ & $\begin{array}{l}\text { Mengorganisir kegiatan } \\
\text { pemanfaatan pasir dan } \\
\text { batu di sungai }\end{array}$ & $\begin{array}{l}\text { Berbasis Hak, } \\
\text { Struktural Dan } \\
\text { Relasional }\end{array}$ & $\begin{array}{l}\text { Menjalin relasi } \\
\text { dengan } \\
\text { pihak otoritas, } \\
\text { Relasi } \\
\text { sosial, } \\
\text { Pengetahuan, } \\
\text { modal }\end{array}$ \\
\hline $\begin{array}{l}\text { Penambang Pasir \& } \\
\text { batu }\end{array}$ & $\begin{array}{l}\text { Pengumpulan/Pengalian } \\
\text { pasir dan batu di sungai }\end{array}$ & $\begin{array}{c}\text { Berbasis Struktural } \\
\text { Dan Relasional }\end{array}$ & $\begin{array}{l}\text { Menjalin relasi } \\
\text { dengan } \\
\text { pihak otoritas }\end{array}$ \\
\hline
\end{tabular}


Masyarakat sekitar Memperoleh tambahan Berbasis Struktural Menjalin relasi lokasi

pendapatan lain

Dan Relasional sosial

Sumber : Hasil Olah Data Riset.

\section{A. Pemerintah Desa Cemplang.}

Pemerintah desa Cemplang merupakan aktor yang memiliki kewenangan dan kekuasaan dalam mengelola sumberdaya alam di desa termasuk di sungai Ciante, di mulai dari perumusan kebijakan, pelaksanaan hingga pengawasan dan pengendaliannya. Kekuasaan yang dibangun melalui mekanisme berbasis hak, structural dan relasional yaitu dengan memberikan hak ijin bagi pemilih lahan/penambangan pasir yang dilakukan secara informal melalui relasi kewenangan yang terjalin. Kekuasaan yang dibangun melalui mekanisme akses ini menjadi modal dasar bagi para pemilik lahan penambangan untuk lebih leluasan menjalankan usaha ini.

Seyogjanya masyarakat yang melakukan penambangan pasir harus mempunyai ijin pertambangan rakyat (IPR) yang diberikan oleh pemerintah setempat seperti yang tercantum dalam pasal 1 ayat 10 UU No.4 tahun 2009 tentang Pertambangan mineral dan batu bara. Pemerintah Desa belum tegas dalam menerapkan aturan ini. Pemerintah desa berpandangan bahwa para penambang pasir ini merupakan masyarakat yang ada di wilayahnya dan yang memiliki pendapatan rendah dan hasilnya digunakan hanya untuk kebutuhan sehari-hari, serta kegiatan masih bersifat tradisional. Selain itu aktifitas ini cukup membantu memberikan retribusi bagi pembangunan desa. Pemerintah desa tidak mensosalisaskan peraturan ini dengan baik bagi masyarakat terlebih dengan terbitnya UU 23 tahun 2014 yang menjadikan izin galian C menjadi kewenangan dinas Energi Sumber Daya Mineral (ESDM) Provinsi.

Relasi kuasa yang dibangun melalui mekanisme structural dan relasional dengan memanfaatkan identitas sebagai Pemerintah desa yang berhak dalam melakukan pengelolaan dan pemanfaatan sumberdaya DAS tersebut. Pemilik usaha penambangan ini bahkan di kuasai oleh tokoh pemerintah desa. Kerjasama yang terjalin memberikan komitmen untuk kedua pihak agar saling membantu terutama memberikan retribusi bagi desa dan wajib mendukung perbaikan sarana umum di desa melalui usaha penambangan ini. Hal ini memperlihatkan bahwa Pemerintah desa adalah aktor utama, yang memiliki kekuasaan lebih banyak untuk mempengaruhi aktor lain (pemilik tambang dan penambang) dalam mengontrol, mempertahankan (memanfaatkan) dan memelihara sumber daya yang tersedia ini.

\section{B. Pemilik/pengusaha lahan penambangan}

Pemilik penambangan memiliki kepentingan yaitu mengorganisir kegiatan pemanfaatan pasir dan batu di sungai. Pemilik menjalankan mekanisme akses relasional dan struktural yaitu memanfaatkan relasi yang ada dengan pemerintah desa dan para penambang pasir. Serta pemilik memainkan aksesnya dengan penguasaan terhadap modal, tenaga kerja, pengetahuan, dan identitas sosial yang memperkuat akses pemilik ke pengelolaan penambangan pasir ini.

Penghasilan dari galian c yang tidak seberapa tersebut, ditambah izin yang harus melalui dinas ESDM Provinsi dimana membutuhkan biaya dan waktu yang tidak sedikit, maka para pemilik penambang lebih memilih untuk tidak mengurus perizinan daripada harus "berepot-repot" mengurusi proses perizinan tersebut yang belum tentu juga langsung ditanggapi dan dilayani oleh pihak yang bertanggung jawab atas proses tersebut. Terlebih 
telah mengantongi ijin dari Pemeritah desa sehingga usaha ini dapat terus dikembangnya serta terjamin keberlangsunganya.

Kekuasaan pemilik usaha ini adalah dengan menjalin relasi dengan pihak otoritas, modal, relasi sosial, dan pengetahuan terurai sebagai berikut :

Akses modal yang di miliki pemilik mempengaruhi kewenangan pemerintah desa dalam pelanggaran ijin penambangan pasir ini. Akses modal ikut mempengaruhi kewenangan pemerintah setempat seperti kepala desa. Relasi kekuasaan yang baik dengan kepala desa memudahkan pembuatan surat keterangan tanah dari lahan yang dimiliki serta dukungan pemerintah setempat terhadap keberadaan tambang pasir di wilayah kekuasaannya. Akses modal juga mampu membuat pengusaha merendam dampak sosial dan lingkungan yang muncul akibat aktifitas ini. Pengusaha berpartisipasi dalam kegiatan sosial antaralain : Pembangunan jalan desa, pembangunan rumah ibadah dan pembangunan balai desa serta berpartisipasi dalam perayaan hari besar keagamaan dan lain-lain.

Akses tenaga kerja dilakukan dengan cara mempekerjakan masyarakat setempat dimana ada pengusaha yang secara khusus memperkerjakan tenaga khusus untuk penambangan pasir dan ada yang menyewakan lahan untuk ditambang pasirnya oleh masyarakat setempat. Perekrutan tenaga kerja adalah dikhususkan pada masyarakat setempat. Kegiatan pengamananpun melibatkan masyarakat setempat.

Akses pengetahuan dapat dilihat dari wacana yang dikembangkan mengenai manfaat galian pasir bagi kebutuhan pembangunan dan pendapatan masyarakat, sumber PAD dan membuka akses jalan desa yang lebih baik. Wacana ini membuat keberadaan tambang pasir menjadi lebih penting dibandingkan keberadaan fungsi hulu DAS, sehingga implementasi kebijakan pemerintah desa lebih berpihak pada aktifitas penambangan pasir ini.

Akses pengusaha melalui identitas sosial dapat dilihat dari relasi yang terjalin antara pengusaha yang sama-sama berprofesi sebagai penambang pasir. Akses ini memungkinkan pengusaha saling bekerjasama diantara mereka dalam mengembangkan pengetahuan dan pengelolaan usaha ini. Selain itu relasi sosial terjalin baik antara pengusaha dengan pembeli baik pedagang perantara maupun pembeli langsung. Belum ada organisasi yang memayungi aktifitas mereka namun para penambang cenderung berkelompok sesuai kepemilikan lahan olahan tersebut.

\section{Penambang Pasir}

Relasi kuasa Penambang pasir dengan pemilik tambang lebih kepada kerjasama dalam pengembangan usaha ini. Hubungan penambang dengan pemilik tambang yang berada di wilayah desa Cemplang ini telah lama terjalin baik, untuk kepentingan pemanfaatan sumberdaya pasir dan batu ini maupun dengan akses pemasaran hasil penambangan tersebut. Hubungan kerjasama dalam kekuasaan ekonomi politik ini bertujuan untuk melakukan pengelolaan dan pemanfaatan sumberdaya alam khusus pasir dan batu di sungai Ciaten. Para penambang dilibatkan sebagai tenaga kerja ataupun penyewa lahan. Mekanisme akses berbasis struktural Dan relasional dimana memiliki hak dan relasi untuk bagi hasil dengan pemilik ataupun membayar biaya sewa lahan untuk aktifitas penambangan tersebut. Para penambang ini ditentukan adalah masyarakat desa Cemplang dan tidak di ijinkan untuk pendatang karena bertujuan sebagai lapangan kerja bagi masyarakat desa.

\section{Masyarakat desa}

Masyarakat desa memiliki pemahaman bahwa sungai adalah sumber penghasilan mereka (penambangan pasir dan kerambah ikan) dan tempat mereka beraktivitas setiap hari (mencuci dan mandi). Masyarakat berpandangan bahwa aktivitas penambangan ini tidak merusak lingkungan karena galian pasir memanfaatkan pasir yang terbawa ketika hujan deras dan mencegah pendangkalan sungai serta dilakukan secara tradisional. Rendahnya penghasilan masyarakat yang sebagian besar berprofesi sebagai petani dan kuli bangunan 
telah mendorong penjualan lahan-lahan masyarakat yang berdekatan dengan sungai dan beralih profesi sebagai penambang pasir.

Kepentingan dari masyarakat melalui aktifitas ini adalah sebagai pendapatan bagi keluarga terutama bila sungai banyak menghasilkan pasir khususnya pada musim hujan. Selain itu akses jalan desa menjadi lebih baik karena dari hasil ini telah banyak membantu memperbaiki jalan desa dan mendukung kegiatan keagaman di desa. Akses jalan yang baik ini berhubungan juga dengan transportasi pengangkutan pasir dan batu agar lebih lancar. Masyarakat desa sekitar memiliki mekanisme akses berbasis struktural Dan relasional yakni relasi yang relasi social sebagai tenaga kerja penambang pasir dan berperan dalam mendukung pengamanan aktifitas ini.

\section{Identifikasi mekanisme memperoleh, mengontrol dan mengatur yang dilakukan oleh aktor.}

Upaya memperoleh akses penambangan pasir ini, di mulai melalui inisiatif beberapa tokoh pemilik lahan yang melihat potensi yang tersedia pada lahan mereka. Pemilik lahan telah menjalankan aktifitas ini \pm 40 tahun. Aktifitas penambangan ini bersifat tradisional dan disebut masyarakat dengan istilah "proyek". Masyarakat hanya mengunakan lingis, sekop dan saringan pasir untuk pengerjaannya Seluruh masyarakat diberikan akses untuk terlibat pada aktifitas ini. Upaya memperoleh akses tambang dilakukan dengan menyampaikan ijin kepada pemilik lahan. Masyarakat memiliki ketertarikan yang cukup tinggi dengan alasan sebagai mata pencaharian yang sangat mudah di tekuni oleh mereka. Akses untuk keterlibatan dalam kegiatan ini diperoleh melalui akses kepemilikan lahan yang terbagi atas 2 cara yaitu 1).Pemilik yang mempekerjakan masyarakat tertentu sebagai penambang pasir seperti yang dikelola oleh Haji Elik di kampung pasir angin dimana ia mempekerjakan 2- 3 orang masyarakat yang secara khusus menambang pasir yang dimasukan pada karung plastik, tenaga ini dibayar berdasarkan jumlah karung pasir yang dihasilkan dan kemudian dijual oleh pemilik ini bagi pembeli yang berminat. 2). pemilik lahan yang menyewakan lahannya bagi beberapa penambang pasir seperti yang dikelola oleh Bpk Komar dan Bpk Endang. Dimana masyarakat penambang pasir yang berada pada wilayah kepemilikan tertentu akan diatur oleh pemilik lahan terhadap bagian kavling galian yang ditunjuk. Galian pasir tersebut akan ditampung dan diangkut dalam 1 mobil pickup tertentu. Penambang galian memiliki hak penuh atas penjualan (per mobil pickup) dan hanya memberikan retribusi harian antara $\mathrm{Rp} 6000$,- dan $\mathrm{Rp} 25.000$,-perhari tergantung kesepakatan yang di buat bagi pemilik lahan. Retribusi ini diolah pemilik tambang untuk kegiatan sosial misal pembangunan jalan, rumah ibadah dan kegiatan keagamaan dan lain-lain.

Upaya mengontrol aktivitas ini dilakukan dan diatur penuh oleh sistem kepemilikan penambangan yang berlaku. Untuk pemilik yang mempekerjakan tenaga penambang di kontrol penuh oleh pemilik lahan tersebut, baik pengaturan dilapangan hingga proses penjualannya. Hasil galian perkarung dijual pemilik lahan tersebut secara langsung ke pembelinya. Untuk pemilik lahan yang menyewakan lahannya. Pengontrolan baik dari proses pengolahan dilapangan hingga penjualannya di atur oleh masing-masing penambang berdasarkan lahan galian yang diolahnya dimana setiap galian di angkut dan dijual per pickup mobil oleh masing-masing penambang sesuai dengan kesepakatan yang terjalin dengan pembelinya. Tiap lahan di buat kavling pada pesisir sungai dengan ukuran tertentu oleh masing-masing penambang pasir dan didasarkan pada struktur galian secara alami yang telah terbentuk. Batasan tiap kavling galian dibatasi oleh bebatuan yang sengaja di tata atau yang telah terbentuk secara alami. Pengamanan dilakukan oleh masing-masing penambang dan didasarkan atas kepercayaan yang terbangun antar sesama penambang pasir.

Upaya mengatur aktivitas penambangan pasir ini tidak berbeda dengan aktivitas pengontrolan yang di lakukan dimana didasarkan pada bentuk kepemilikan yang berlaku. Kegiatan penambangan rutin dilakukan tiap pagi hingga sore hari dan disesuikan dengan waktu yang disediakan oleh penambang. Pembeli galian pasir ini berasal dari dalam desa, desa-desa sekitar hingga kota Bogor. Pasir galian dari daerah ini sudah cukup dikenal baik kualitasnya oleh masyarakat pemakai.Satu pickup mobil untuk galian pasir yang diangkut di 
hargai sebesar Rp 70.000,- Rp 80.000,-. (Nurromansyah.A.N dan Setyono.J.S, 2014) menyampaikan bahwa pemanfaatan sumberdaya alam oleh masyarakat di Sub DAS adalah aktivitas pemanfaatan sumberdaya alam untuk pemenuhan kebutuhan pokok dan juga kebutuhan ekonomi. Aktivitas pemanfaatan sumberdaya ini dapat mempengaruhi penurunan fungsi DAS. Kegiatan penambangan ini akan memberikan Implikasi bagi lingkungan antara lain vegetasi sekitar reparian sungai mengalami kerusakan dan mudah longsor, Air sungai cenderung keruh bila aktifitas kegiatan ini meningkat, batu-batuan sungai di rusak karena diambil untuk dijual dan bekas galian dibiarkan tanpa ditata lagi sehingga fungsi sungai tergangu. Masyarakat belum memiliki pemahaman yang baik tentang dampak dari kegiatan penambangan ini bagi lingkungannya. Untuk itulah peran berbagai pihak sangat dibutuhkan untuk menambah pengetahuan masyarakat serta meningkatkan sumberdaya masyarakat setempat melalui kegiatan ekonomi produktif. Selain itu, kegiatan ini memberikan implikasi sosial ekonomi bagi masyarakat setempat yaitu 1). tersedia lapangan kerja lagi masyarakat setempat, hal ini yang menjadi alasan utama kegiatan ini terus dikembangkan, 2). Status sosial masyarakat berpotensi menimbulkan upaya penguasaan lahan dan persaingan memperoleh hasil pasir dan batu dan 3). timbulnya konflik karena kecenderungan membatasi aktifitas ini terutama bagi masyarakat tertentu yang memiliki hubungan baik dengan pemilik lahan atau aparatur desa. (pendatang tidak diperkenankan untuk ikut bekereja). Meski demikian sejauh ini konflik yang ada masih dapat di selesaikan secara kekeluargaan.

Pemerintah seringkali merasa bimbang. Pada satu sisi mereka mengatahui bahwa aktifitas masyarakat di sekitar DAS ini merupakan pelanggaran hukum, tetapi di sisi lain bahwa masyarakat memiliki alternatif pendapatan dari aktifitas penambangan pasir ini. Menurut (Zubayr.M, Darusman.D,Nugroho.B, 2014) partisipasi aktif masyarakat lokal menjadi penting karena masyarakat merupakan bagian dari ekosistem lingkungannya yang memiliki hak untuk mendapat kesempatan mengelola sumberdaya lokal dan pembangunan harus mampu menyejahterakan masyarakat, memelihara kondisi lingkungan yang baik serta mengintegrasikan kepentingan manusia secara optimal yaitu kepentingan ekonomi,sosial budaya dan ekologi. Untuk itulah sangat dibutuhkan kerjasama berbagai pihak dalam mengembangkan sumberdaya manusia dan lingkungan dari masyarakat setempat. Peningkatan pemahaman dan peran serta masyarakat dalam peningkatan kesejahteraan dan memelihara kelestarian fungsi dan manfaat DAS perlu dilakukan melalui kegiatan penyuluhan dan kegiatan pemberdayaan masyarakat.

\section{KESIMPULAN}

Relasi kekuasaan dalam pengelolaan sumber daya pasir dan batu di sungai Ciaten ini setidaknya terdapat beberapa aktor yang saling berinteraksi yaitu pemerintah desa, pemilik/pengusaha penambangan, penambang pasir dan masyarakat sekitar lahan penambang pasir.

Keempat aktor ini memiliki mekanisme akses berbasis Hak, Struktural dan Relasional dimana Pemerintah desa Cemplang merupakan aktor utama yang memiliki kewenangan dan kekuasaan dalam mengelola sumberdaya alam di desa termasuk sumberdaya pasir dan batu di sungai Ciante, Pemilik tambang menjalankan mekanisme yaitu memanfaatkan relasi yang ada dengan pemerintah desa dan para penambang pasir dimana pemilik memainkan aksesnya dengan penguasaan terhadap modal, tenaga kerja, pengetahuan, dan identitas sosial yang memperkuat akses pemilik ke pengelolaan penambangan pasir ini, Penambang pasir memiliki hak dan relasi untuk bagi hasil dengan pemilik ataupun membayar biaya sewa lahan untuk aktifitas penambangan tersebut, Masyarakat sekitar memiliki akses yaitu relasi social dengan kerjasama ikut serta sebagai penambang pasir.

Upaya memperoleh akses penambangan pasir ini, di mulai melalui inisiatif beberapa tokoh pemilik lahan yang melihat potensi yang tersedia pada lahan mereka. Upaya mengontrol aktivitas ini dilakukan dan diatur penuh oleh sistem kepemilikan penambangan 
yang berlaku serta Upaya mengatur aktivitas penambangan pasir ini tidak berbeda dengan aktivitas pengontrolan yang di lakukan dimana didasarkan pada bentuk kepemilikan yang berlaku

\section{UCAPAN TERIMA KASIH}

Penulis menyampaikan terimakasih kepada Kementerian Riset, Teknologi dan Pendidikan Tinggi Republik Indonesiayang telah memfasilitasi biaya bagi penelitianini melalui hibah Desentralisasi Dosen Pemula tahun 2016 dengan No SPH :2412/ K4/KM/2016 Tanggal 27 Mei 2016 dan terima kasih juga disampaikan penulis kepada Desi Dritasari dan Vanny Febriany, alumni mahasiswa Universitas Nusa Bangsa yang telah sangat membantu penulis dalam pengambilan data di lapangan.

\section{DAFTAR PUSTAKA}

Alberto et. al. 2010. (2110). Model Perubahan Penggunaan Lahan dan Pendugaan Cadangan Karbon di Daerah Aliran Sungai Cisadane, Jawa Barat". Jurnal Agromet IPB, 24(2), 18-26.

BPDAS Citarum-Ciliwung. (2010). Pengelolaan DAS Cisadane Terpadu Tahun 2010.

Bryant R.L. (1998). Bryant, R.L. 1998. Power, Knowledge, and Political Ecology in the third world: a Review. Journal Proggress in Pshysical Geography, 22(1), 79-94.

Bryant R.L and, \& Bailey, S. (1997). Third World Political Ecology. (2nd ed.). London and New York: Routledge.

Buckles, D. (1999). Buckles, D. 1999. Cultivating Peace; Conflict and Collaboration in Natural Resources Management. International Development Research Center (IDRC) in collaboration with The World Bank Institute. Ottawa. Canada.

Febryano, I.G., D. Suharjito, D. D. dan C. K. (2015). Aktor dan Relasi Kekuasaan Dalam Pengelolaan Mangrove Di Kabupaten Pesawaran. Jurnal Analisis Kebijakan Kehutanan. Vol. 12 No.2.

Nurromansyah.A.N dan Setyono.J.S. (2014). Perubahan kesiapsiagaan Masyarakat DAS Beringin Kota Semarang dalam menghadapi Ancaman Banjir Bandang. Jurnal Wilayah Dan Lingkungan, 2(3), 231-244.

Pemerintah Indonesia.2009. Undang-Undang No. 4 tahun 2009 tentang Pertambangan Mineral dan Batubara.

Pemerintah Indonesia.2009. Undang-Undang No. 32 tahun 2009 tentang Perlindungan dan Pengelolaan Lingkungan Hidup.

Pemerintah Indonesia.Peraturan Pemerintah No. 55 tahun 2010 tentang Pembinaan dan Pengawasan Penyelenggaraan Pengelolaan Usaha Pertambangan Mineral dan

Pemerintah Indonesia. Peraturan Pemerintah No. 24 tahun 2012 tentang Perubahan atas Peraturan Pemerintah No. 23 tahun 2010 tentang Pelaksanaan Kegiatan Pertambangan Mineral dan Batubara,

Pemerintah Indonesia.Instruksi Presiden No. 1 tahun 2012 tentang Pelaksanaan dan Pengawasan terkait Kegiatan Usaha Batubara.

Ribot. J.C and Peluso.N.L. (2003). A theory of access. Rural Sociology, 68(2), 153-181.

Salampessy.M.L, Lidiawati.I.2017. Potensi Kelembagaan Lokal dalam Pengelolaan Daerah Aliran Sungai (Studi Kasus Di Desa Cemplang, Sub Das Ciaten Hulu Timur Das Cisadane). Jurnal Hutan Tropis Vol. 5 No. 2 Juli 2017, 113-119.

Trimarmanti.T.K.E. (2014). Evaluasi Perubahan Penggunaan Lahan Kecamatan di Daerah Aliran Sungai Cisadane Kabupaten Bogor. Jurnal Wilayah Dan Lingkungan, 2(1), 5572.

Wegenast.T. and Schneider. G. (2017). Ownership matters: Natural resources property rights and social conflict in Sub-Saharan Africa. Political Geography Journal., 61, 110- 
122. https://doi.org/10.1016/j. polgeo.2017.07.007

Yin.R.K,(1997). Studi Kasus.Desain dan Metode.PT Raja Grafindo Persada.Jakarta.

Zubayr.M, Darusman.D,Nugroho.B, N. D. . (2014). Peranan Para Pihak Dalam Implemantasi Kebijakan Pengunaan Kawasan Hutan Untuk Pertambangan. Jurnal Analisis Kebijakan Kehutanan, 11(3 Des 2014), 239-259. 